\title{
Die skoolorde van Genève 1559: 'n Basis vir 'n gereformeerde skoolorde
}

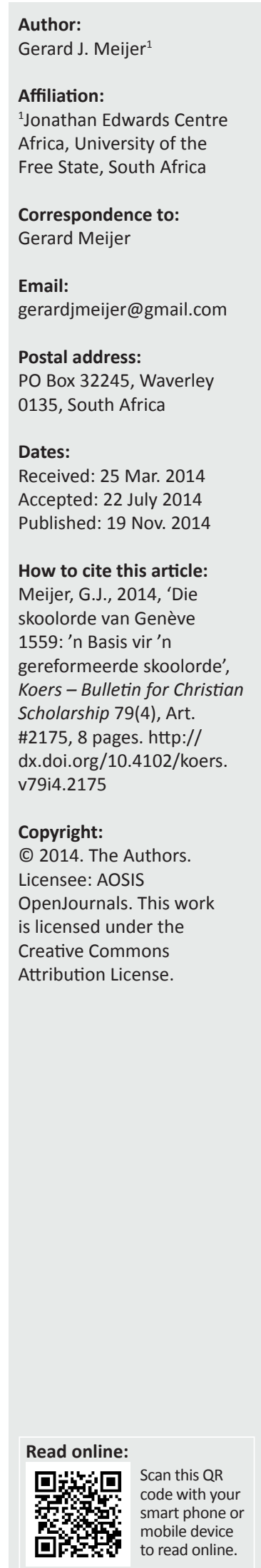

Calvyn en die onderwys is sinoniem. Behalwe dat sy geskrewe nalatenskap van sy intense besig wees mét en liefde vír die onderwys getuig, het hy hom konkreet vir die daarstel van skole beywer waar die jeug in die vrees van die Here opgevoed word. Nie alleen die inhoud van die onderrig wat die kinders ontvang nie, maar ook die vorm waarin dit aangebied word, asook die leerkragte wat daarby betrokke is, het besondere aandag by Calvyn gekry. Oor alles laat hy die lig van God se Woord skyn. In hierdie artikel word aangetoon hoe hy, gegewe sy eie historiese agtergrond, met die middels tot sy beskikking in die stad Genève gepoog het om 'n skoolstelsel te ontwerp waar kinders en jongmense onderrig word ooreenkomstig die doopsbelofte wat die ouers afgelê het. Calvyn se Geneefse skoolorde van 1559, in samehang met die Geneefse Kerkorde van 1561, gee insae in sy denke en optrede betreffend die onderwys. 'n Poging word aangewend om enkele lyne te trek wat hopelik vir die huidige onderwysgesprek bruikbaar sal wees. Die vraag is of daar te midde van al die skoolbeleide en skoolreëls 'n dringende behoefte aan 'n deeglike grondliggende skoolorde is. Die artikel wil aan hierdie vraag aandag skenk.

The school order of Genève 1559: A basis for a reformed school order. Calvin and education are synonymous. Apart from his written legacy, which speaks of his intense love for education, he endeavoured to put schools in place where young people could be educated in the ways of the Lord. This was not only in the curriculum, but also in the way it was presented and the teachers who presented those lessons received special attention from Calvin. The light of God's Word is shed over everything. This article shows how, given his own historical background and the tools available to him, he tried to develop a school system in the city of Geneva where children could be educated in accordance with the promise of their parents at their baptism. The school order of Geneva (1559) in conjunction with the Genevan Church order (1561) gives us insight in the doings and thoughts of Calvin on education. I hope to indicate some lines that could be of use in the present dialogue on educational matters. Sadly, the way Calvin set up a system for education is no longer evident in schools. Isn't there an urgent need for a well-defined and fundamental school order amongst all the school policies and rules? This question will receive attention in the article.

\section{Inleiding}

Dit is nie moontlik om aan die gereformeerde kerkwees te dink sonder om direk daarmee saam aan die gereformeerde onderwys te dink nie. Hiérdie twee loop hand aan hand. In sy Woord roep die Here ouers op om die kinders van die verbond Godvresend op te voed. ${ }^{1}$ Die opvoeding van kinders bevat talle fasette. In die huisgesin moet die nodige aandag aan kinders se groei na volwassenheid gegee word. Kerklik is daar kategetiese en ander onderrig. Op skool word kinders volgens 'n kurrikulum onderrig wat hulle vir die lewe as volwassenes toerus. Al die onderrig vloei voort uit die ouers se belofte wat hulle by die doopvont afgelê het. ${ }^{2}$

Wat die skoolonderwys in Suid-Afrika betref, is daar baie invloede wat direk in stryd is met die belofte wat by die doopvont afgelê is. Nie alleen die inhoud ${ }^{3}$ van die leerstof nie, maar ook die vertrekpunte 4 en die wyse van aanbieding getuig van 'n ander gees as die Gees van God wat in ons werksaam moet wees.

\section{Vergelyk die volgende teksgedeeltes: Deuteronomium 6:4; Psalm 78:3-8; Spreuke 22:6; Efesiërs 6:4; Kolossense 3:21.}

2.Die derde vraag van die klassieke doopsformulier in die Psalmboek (GKSA 2009:115) lui soos volg: 'Belowe u en neem u u voor om hierdie kind, van wie u die vader en/of moeder is, wanneer hy of sy dit kan verstaan, in die genoemde leer te onderrig en te laat onderrig?'

3.Wanneer ondersoek gedoen word na die inhoud van die Suid-Afrikaanse regering se sillabusse, word dit duidelik watter onderliggende ideologieë en dogmas verkondig word (kyk Suid-Afrika 2014).

4.Die Suid-Afrikaanse regering beskou elke skoolkind as 'n 'nasionale bate', soos weerspieël word in die logo van die Departement van Onderwys. 
Die gereformeerde skole wat tans in Suid-Afrika is, het konstitusies en skoolreëls, maar geen skoolorde soos wat Calvyn opgestel het nie. 'n Konstitusie en skoolreëls spruit logies uit 'n skoolorde voort. Trouens, alle beleide en besluite van 'n gereformeerde skool behoort uit 'n deeglik deurdagte skoolorde voort te spruit. 'n Skoolorde bied die basis waarop die skool as unieke samelewingsverband leef en werk (Buys 2010:24). ${ }^{5}$

\section{Historiese agtergrond}

Op 05 Junie 1559 - vyf weke voor Calvyn se vyftigste verjaarsdag - vind die amptelike opening van die Akademie te Genève plaas (CO 10a 65; Nauta 1959:7, 21). Op daardie dag het 'n lank gekoesterde en vurig begeerde ideaal vir Calvyn werklikheid geword (Coetzee 1959:45; Nauta 1959:8). In dieselfde jaar is ook die laaste, hersiene en bygewerkte uitgawe van sy Institusie uitgegee. Hierdie twee gebeurtenisse staan nie los van mekaar nie. Verskillende aktiwiteite en werke in Calvyn se kortstondige, vol lewe word hierdeur tot 'n geheel in mekaar verweef. Die onderwysing wat in sy Institusie opgeteken staan en die onderwys aan die Akademie kan nie van mekaar geskei word nie.

Die Akademie in Genève het nie oornag tot stand gekom nie (Maag 2000:11). Reeds in 1536, tydens sy eerste verblyf in Genève, het Calvyn saam met Farel, sy kollega, die eerste boustene vir die Akademie begin lê. Op daardie stadium was Calvyn nie die amptelike predikant van Genève nie (Nauta 1959:9). Hy was as lector (professor) in die Heilige Skrifte aan die skool wat toe reeds in Genève bestaan het, verbind (Nauta 1959:9). Sy besondere taak was om saam met Farel voorlesings uit die Heilige Skrif te lewer. Hy het voortgegaan om hierdie werk te doen, selfs nadat hy predikant in Genève geword het. Aan die begin van 1538 is die skool van Genève opnuut georganiseer. 'n Hersiene studieprogram is opgestel (Nauta 1959:10) waarin die voorlesings uit die Skrif 'n afsonderlike onderdeel gevorm het. Daarby is openbare debatvoering (disputations) oor die Christelike godsdiens gevoeg (Nauta 1959:10). Hierdie debatvoerings het wesenlik ' $n$ ander karakter gehad as die debatte wat aan ander skolastiese instellings gevoer is. Daar is geen ruimte vir 'n geskree, strydlus en wyshede (sofismes) gelaat nie. Bowendien is die debatte nie alleen tot teoloë-inopleiding beperk nie, maar die opleiding van onderwysers is eweneens in die oog gehou (Nauta 1959:10).

Ná sy terugkeer na Genève in 1541 het Calvyn hom met nuwe ywer aan die daarstel van 'n skool, gebaseer op 'n deeglike skoolorde, begin toelê. Dit blyk by uitstek uit die verwysing wat hy in die Kerkorde van 1541 na die doktoreamp maak (Nauta 1959:10). Doktore moet sorg dra vir die onderwys. Met die oog op 'n grondige onderrig in die Teologie was onderwys in die tale en lettere 'n onmisbare voorwaarde. Sodanige onderrig moes aan 'n College verskaf

5.Buys (2010:151) beklemtoon dat die skoolorde in die kader van die verbond staan, naamlik: 'Dat Christus as Hoof van die skepping gesag het oor alle dinge, ook spesifiek oor menslike onderwys, is belydenis. Hoe daardie gesag in die skool verwesenlik word, behoort in 'n verbondsmatige skoolorde verder uitgewerk te verwes
word'. word wat spesiaal vir dié doel geopen is. Calvyn het dit van meet af aan duidelik bekend gemaak dat die opleiding aan die College nie slegs toegang tot teologiese opleiding 6 gee nie, maar dat dit ook as voorbereiding vir diens in die staat en die stad geld (Nauta 1959:11). 'n Verdere bepaling het betrekking op die benoeming van leraars, asook skoolmeesters aan die laerskole gehad. Laasgenoemde behoort met die goedkeuring van die kerk te geskied, onder wie se toesig en tug die dosente en leermeesters staan (Nauta 1959:11).

Sedert 1541 het 18 jaar van stryd en moeite verloop om vanaf ' $n$ geskrewe bepaling in die Kerkorde tot by die daadwerklike oprigting van 'n skool te kom (Nauta 1959:12; Van't Veer 1942:99)7. Eers vanaf 1555 het die stryd egter behoorlik vrug afgewerp. Calvyn het hom vir die verkryging van 'n geskikte gebou en terrein beywer (Strohm 2009:93). En die belangrikste was dat bekwame leraars gevind moes word om die doseerwerk te behartig.

In daardie tyd het Calvyn ernstig siek geword. Vanaf sy siekbed het hy onverpoosd voortgegaan om briewe te skryf, bouwerk te inspekteer en toe te sien dat alles vir die daarstel van die skool in orde sou wees (Nauta 1959:13). Theodorus Beza is in September 1558 as die eerste leerkrag by die skool aangestel. Na enkele maande het meer aanstellings gevolg, sodat die verskillende leerstoele gevul kon word met die oog op die opening van die College en die Akademie.

Op 22 Mei 1559 het Calvyn in die volle sitting van die Raad van Genève verskyn om die finale beplanning aan die opening van die College en die Akademie voor te lê (Nauta 1959:6). In die dokumente wat hy voorgelê het, het hy presiese toeligting verskaf oor die reorganisasie en uitbreiding van die College, die skool vir gimnasiale onderrig, wat die stad toe reeds gehad het. In sy voordrag het hy 'n reglement, 'n skoolorde, voorgelê waarin duidelik uiteengesit is op watter basis die College bedryf sou word (Nauta 1959:127)8. 'n Week later het die Raad van Genève die reglement goedgekeur en nog 'n week later, op 05 Junie 1559 , is die reglement in die openbaar afgekondig waarna die lesse op 06 Junie kon begin. Saam met die reglement het Calvyn ook 'n aantal persone voorgestel wat na sy mening as leraars benoem kon word. Die Raad het ook hierdie voorstelle goedgekeur. Beza is as die eerste rektor van die College benoem.

By die amptelike opening het die sekretaris van die Raad van Genève, Michel Roset, die skoolreglement voorgelees, asook 'n uitvoerige geloofsbelydenis waarmee die studente hulle instemming moes betuig. Daarbenewens was daar 'n eedformule wat deur die rektor en die dosente onderteken moes word (Nauta 1959:8). Hierdie formules het deel van die skoolorde gevorm wat Calvyn opgestel het (CO 10a, 65-90).

6.Die teologiese opleiding was nie tot Genève beperk nie, maar het spoedig internasionale belangstelling gewek (Doumergue 1907:287; Van Veen 2006:71-72).

7.Cordier se insette in hierdie verband moet nie onderskat word nie. Pogings van Calvyn om Cordier aan die skool te verbind, het egter geen positiewe resultate opgelewer nie (Bakhuizen van den Brink \& Dankbaar 1980:161; Nauta 1959:12).

8.Die skoolorde is eers in Latyn uitgegee en later in Frans. 
Om die behandeling van die skoolorde in perspektief te plaas, is dit belangrik om daarop te let dat daar in die College 'n skerp onderskeid gemaak is tussen die private skool (die gereorganiseerde gimnasiale opleiding) enersyds en die openbare of hoërskool (die eintlike Akademie) andersyds. Anders as die Gimnasium, het die Akademie geen verskillende klasse gehad nie. Studente van ongeveer 16 jaar het ná die suksesvolle voltooiing van die sewe klasse in die Gimnasium met hulle lesse by die Akademie begin (Raynal III [1990:129]). Dit moet beklemtoon word dat die Akademie 'n 'eiestandigheid' (Eigenständigkeit) gehad het nie heeltemal los van die kerk en die staat nie, maar beslis ook nie daaraan verkneg nie (Nauta 1959:17, 21).

\section{Oorsig oor die inhoud van die Geneefse skoolorde}

Die skoolorde van Genève 1559 bevat 'n kort inleiding, waarna die volgende sake aan die orde gestel word. ${ }^{9}$

\section{Leermeesters (Regens of Praeceptori) van die College (Gymnasium) (CO 10a, 69)}

Leermeesters is bedienaars van God se Woord wat met 'n goeie en rein gewete onderrig gee. Hulle word deur die Raad (senaat) verkies en moet tot sodanige verkiesing instem. Leermeesters moet betyds in hulle klasse wees en word nie van lesse wat aan hulle opgedra is, vrygestel nie. Indien 'n leermeester ' $n$ les nie kan waarneem nie, moet hy die Rektor betyds in kennis stel sodat alternatiewe reëlings getref kan word.

Lesse moet sonder groot lawaai aangebied word. Geskrifte wat behandel word, moet eenvoudig uitgelê word, sonder dat die skrywer daarvan direk aangeval word. Die skrywer se bedoeling moet duidelik uiteengesit word.

Kinders moet tydens die aanbied van lesse stil en rustig gehou word. Rebelse en ongehoorsame kinders moet ooreenkomstig hulle verkeerde optrede tereggewys word. Die belangrikste is dat leermeesters die kinders onderrig in hulle liefde vir God en teen hulle swakhede stry. Indien nodig, word die Rektor se hulp ingeroep om onmin uit die weg te ruim. Kinders word nie sommer as gevolg van ongehoorsaamheid uit die klasse gestuur nie.

\section{Die Hoof (Principal of Ludimagistro) (CO 10a, 71)}

Die hoof moet 'n man van goeie reputasie wees, Godvresend, suiwer in leer en lewe, met 'n vriendelike persoonlikheid, nie hardvogtig nie, 'n persoon wat vir die leerlinge 'n goeie voorbeeld met sy lewe stel, iemand wat sy werklas met ywer dra.

Sy werk is dieselfde as dié van die leermeesters, naamlik om sy klas te onderrig. Daarbenewens moet hy oor die personeel toesig hou. Hy moet toesien dat alles in die College vlot verloop, die klokke vir die periodes betyds lui en goeie orde in die College gehandhaaf word. Probleme met personeel asook leerlinge word deur die Rektor gehanteer.

\section{Leerlinge (escholiers of scholastics) van die skool (CO 10a, 71)}

Al die skoliere word deur die leraars op vasgestelde tye na die kerk toe vergesel. By die kerk ontvang hulle godsdiensonderrig en onderrig in die Kategismus (kyk Calvyn 1981; n.d.). Leermeesters hou toesig oor die kinders se gedrag en meelewing. Hulle moet ook navraag doen of die kinders die preke volg. Waar nodig, moet ongehoorsaamheid en verkeerde optrede bestraf word. Afwesigheid moet noukeurig opgeteken word.

Op Maandae, Dinsdae, Donderdae en Vrydae bestaan die skooldag uit twee sessies, wat in periodes verdeel word, met 'n uur etenstyd. Woensdae word meer tyd aan die onderrig in die leer van die kerk gewy.

Klasse begin met gebed en Skrifonderrig. Daarna word noukeurig op bywoning en stiptheid gelet. Laatkom is geen verskoning nie. Gedurende die oggend word tyd vir selfstudie in die Skrif en stilgebed ingeruim. In die middag word Psalms aangeleer. Daarbenewens word die Franse taal aangeleer, asook onderrig gegee in die geloofsbelydenis en die Onse Vader.

By tye is daar gemeenskaplike klasse. Tydens hierdie klasse kry die senior leerlinge die geleentheid om 'n lesing voor te dra. Dan moet die junior leerlinge opskryf wat hulle geleer het. Hulle geskrewe werk word ingegee en deur die leermeesters nagegaan.

Op Saterdae vind hersiening plaas. Saterdagmiddae vind daar vir een uur lank 'n debat plaas. Om 15:00 word die klasse verdaag.

Op Sondae is die eredienste en die bywoning van kategese verpligtend.

\section{Leerplan}

Sewende klas: ${ }^{10}$ Die leerlinge leer die alfabet aan, asook woorde en lettergrepe. Frans en Latyn word aangeleer en die Latyns-Franse Kategismus word onderrig.

Sesde klas: Die klem val op die verdere aanleer van Latyn en Frans. Die leerlinge word geleer om Latyn te praat.

Vyfde klas: Onderrig in spraak en oratoriese vermoëns asook sintaksis kry aandag. Die leerlinge leer om hulle eie stukke te skryf.

Vierde klas: Die leerlinge moet sintaksis heeltemal onder die knie kry. Eenvoudige werke van Cicero word gelees en daar word begin met die aanleer van Grieks.

10.Die sewende klas is die eerste skooljaar. 
Derde klas: Verdere onderrig in Grieks, veral grammatika, vind plaas. Die klem val op die verband tussen Grieks en Latyn.

Tweede klas: Onderrig in die Latynse geskiedenis, asook die studie van Griekse en Latynse poësie geskied. Op Saterdae word die Griekse Nuwe Testament (Evangelies) bestudeer.

Eerste klas: Die klem val op spraakkuns; dit is die leerlinge se eerste kontak met dialektiek en retoriek.

Klassieke geskrifte van onder andere Cicero, Homeros en Virgilius word bestudeer om die wyse van debatvoering te ontdek en te bemeester.

Op Saterdae, tussen 15:00 en 16:00, word die briewe van die apostels deurgegaan.

\section{Rektor}

Die Rektor word uit die Raad van predikante en professore gekies. Almal moet tot sy aanstelling instem. Hy moet aan sy Godsvrees en diensbaarheid geken word. Sy taak is om onopgeloste haakplekke tussen die leermeesters uit te sorteer en op die basis van die Skrif gesag te handhaaf. In al hierdie sake is en bly die Rektor ' $n$ Woordbedienaar. Hy is verantwoordelik vir bepaalde administratiewe take en word vir 'n periode van twee jaar gekies.

\section{Verlof}

Tydens die oes van die wingerde word drie weke verlof aan die leerlinge toegestaan.

\section{Bevordering}

Bevordering van een jaargroep na 'n volgende geskied op grond van deeglike eksaminering. Leerlinge moet vrae in Latyn en Frans sonder enige hulp kan beantwoord. Die geskrewe antwoorde word aan die Rektor voorgelê sodat beslis kan word of 'n leerling die verlangde resultate bereik het. Die uitslae word in die openbaar bekend gemaak.

\section{Professore $^{11}$}

Drie professore word aangestel, naamlik in Hebreeus, Grieks en Lettere (arts).

Op Maandae, Dinsdae en Donderdae gee elkeen van hulle twee ure onderrig. Woensdae en Vrydae moet hulle een uur onderrig gee.

Die professor in Hebreeus gee na die oggendgodsdiens 'n uiteensetting van die Hebreeuse teks en grammatika asook 'n verklaring (eksegese) van 'n spesifieke Bybeldeel. Na die middagete doseer hy Hebreeuse grammatika.

Die Griekse professor volg dieselfde werkwyse as die Hebreeuse professor. Hy behandel ook Griekse filosofie

11.Publici professores is dosente wat met voortgesette opleiding aan die schola publica (openbare skool) gemoeid is.
(Aristoteles, Plato, Plutarchus of 'n Christelike filosoof). Na ete behandel hy Griekse gedigte en 'n geskiedskrywing.

Die professor in Lettere doseer spraakkuns en retoriek aan die hand van Cicero of Aristoteles.

\section{Teologiese studente (Publieke skoliere)}

Studente, dit wil sê teologiese studente, kry by die Rektor toestemming om te studeer. Hulle moet spesiaal vir hierdie kursus aan die Akademie inskryf (Coetzee 1959:47). 'n Teologiese student moet die belydenis met sy handtekening onderskryf en hulle name word in 'n boek opgeteken. Op Saterdae kry hulle die geleentheid om hulle spreekgawes te oefen deur in die openbaar 'n stuk uit die Skrif voor te lees. Hulle staan onder toesig van die predikante. Studente leer die suiwer doktrine, maar word ook aan die boosheid en gevaar van valse doktrines blootgestel. ${ }^{12}$ Hulle moet kundig gemaak word om 'n valse leer te weerlê (spraakkuns). ${ }^{13}$ Wanneer daar 'n meningsverskil tussen ' $\mathrm{n}$ student en 'n dosent ontstaan, word 'n openbare gesprek gevoer, wat onder leiding van die professor in Teologie staan. Die bepaalde professor gee die beslissende woord in die dispuut. ${ }^{14}$ Studente word onderrig in Teologie, Hebreeus, Griekse Etiek, Griekse Retoriek, Fisika of Wiskunde en Dialektiek of Retoriek. Op Vrydae moet hulle kerklike vergaderings en kerklike rade bywoon (Coetzee 1959:47).

\section{Eedswering van die Rektor}

By wyse van eedverklaring word die Rektor aan gehoorsaamheid aan die Woord van God en die soeke na die belange van die skool gebind. Hy belowe om in Godsvrees sy werk te doen en hom onder die gesag te voeg van diegene wat oor hom gestel is.

\section{Eedswering van leermeesters}

Die eedverklaring van leermeesters (doktore) kom in breë trekke op dieselfde as dié van die Rektor neer. Met 'n rein gewete sal hy sy lesse tot opbloei van die skool en die gemeenskap aanbied - tot eer van God.

\section{Die wortels waaruit die Geneefse skoolorde van 1559 gegroei het Calvyn se eie akademiese vorming}

Calvyn se eie akademiese opleiding het in en om Noyon, sy geboorteplek, plaasgevind. Op veertienjarige leeftyd het sy pa hom na Parys gestuur waar hy onder andere Latyn bestudeer het onder Marthurin Cordier, een 12. Hierdie werkwyse kan as begeleide konfrontasie getipeer word.

13.Strohm (2009:93) merk in hierdie verband op: 'Mit der Strassburger Akademie teilt man ebenfalls das Idea der pia eloquentia, der frommen Beredsamkeit. Gegen die spekulativen und lebensfremden logischen Spitfindigkeiten der Scholastik sollte - geschult an der antiken Retorik - der Stoff so gegliedert werden, dass
überzeugend vermittelt und für die Lebengestaltung fruchtbar werden konnte'.

14.Coetzee (1959:47) skryf met betrekking tot die optrede van voornemende predikante: 'Elke teken van opgeblasenheid, beterwetery, onheilige hoogmoed, predikante: 'Elke teken van opgeblasenheid, beterwetery, onheilige hoogmoed,
verkeerde foutvindery moet uit besprekings verban word. Elke tema moet verkeerde foutvindery moet uit besprekings verban word. Elke tema moet
omvattend maar eerbiedig en deemoedig bespreek word. Die professor in Teologie neem die leiding en gee afdoende uitspraak'. 
van die voorlopers van die humanistiese opvoeding (Raynal III [1990:121]). Op verskeie vlakke en vir baie jare het Calvyn die Humanisme van sy jare van binne-uit leer ken. Geskool deur verskeie humanistiese leermeesters het Calvyn die tegniek van humanistiese denke goed bemeester. Daardie tegniek het hy nooit heeltemal afgeskud nie; inteendeel, dit het deel van sy mondering geword om die Skrifte te bestudeer. Die klem op die bestudering van Filologie, Grammatika, Retoriek en Logika (Raynal III [1990:123]) kan in die skoolorde van Genève teruggevind word.

\section{Aansluiting by die College de Versonnex (1428) en die College de Rive}

Soos reeds genoem, het Calvyn nie in Genève met 'n heeltemal nuwe skool begin nie. Daar was 'n skool, geskoei op die beginsels van die Roomse onderwys (Maag 2000:12). Hierdie skool het bekend gestaan as die College de Versonnex, vernoem na 'n vermoënde sakeman wat geld vir die oprigting van die gebouekompleks bewillig het. Hierdie skool se primêre mikpunt was onderrig in die Latynse grammatika. Vir hoër onderwys is geen voorsiening gemaak nie. Die magistrate het die salarisse van die onderwysers betaal en sodoende formeel seggenskap in die organisasie en kontrole van die skool verkry. Die magistrate het selfs besondere seggenskap in die leerplanne gehad. Later het die College de Rive tot stand gekom. Die College de Rive het aansienlik op die leerplan van die College de Versonnex uitgebrei (Maag 2000:14-15; Raynal III [1990:121]).

Met sy koms na Genève het Calvyn 'n grondige verandering teweeggebring, sonder om dit wat in die bestaande stelsel goed was, geheel en al te verwerp. Die invloed van die stadsowerheid op die skool is dramaties ingeperk. Inperking beteken egter nie miskenning van die rol van die owerheid nie. Die burgerlike owerheid het steeds vir finansiering van die geboue en die dosente sorg gedra. Wat van die ou bedeling oorgebly het, was die klem op die aanleer van Latyn. Die leerlinge moes van jongs af geleer word om bo en behalwe hulle moedertaal (Frans) die akademiese taal (Latyn) te kan besig.

\section{Aansluiting by die skool van Sturm in Straatsburg}

Gedurende die drie jaar van sy verblyf in Straatsburg - vanaf 1538-1541 - was Calvyn ten nouste by die skool van Johann Sturm betrokke (Nauta 1959:11). Hy het daar teologiese lesse gegee en eksegetiese voordragte gelewer. Die Skool van Sturm het, afgesien van duidelike ooreenkomste met die skole van die Broeders des Gemeenen Levens, unieke kenmerke van die Humanisme vertoon, waaronder die invloed van Desiderius Erasmus. Die invloed wat saamgedra is, raak nie soseer die gees van die skool nie, maar wel die inrigting daarvan (Van't Veer 1942:120). Eie aan die skool van Sturm was die ordelike opeenvolging van klasse, die verdeling van klasse in kleiner groepies, die jaarlikse plegtigheid van bevordering en die voorbereidende karakter van die onderrig aan die College vir die werk by die Akademie (Coetzee 1959:46). Calvyn het in een belangrike opsig 'n totaal ander koers as Sturm ingeslaan. Hy het besondere sorg aan godsdiensonderrig gegee, wat in die humanistiese skole beslis nie die geval was nie (Strohm 2009:93; Van't Veer 1942:121).

\section{Kerkordelik: Geneefse Kerkorde 1561 (artikels 43-47)}

Die belangrikste grondslag vir die oprigting van 'n gereformeerde Akademie moet egter nie in invloede van buite gesoek word nie. Binne die kader van die Skrifgefundeerde kerkreg en met die oog op die groei van die kerk in Genève, het Calvyn vurig na die daarstelling van 'n eiestandige Akademie bly soek. Artikels 43-47 van die Geneefse Kerkorde van 1561 (in uitbreiding op sy Ordonannces van $1541^{15}$ ) verwoord die amp en roeping van die skoolleraars of doktore soos volg:

43. Die regmatige taak van die doktore is om die gelowiges te onderrig in die heilige leer sodat die suiwerheid van die evangelie nie geskaad word deur onkunde of verkeerde opvattings nie. Nietemin, soos sake vandag gesteld is, verstaan ons hieronder: hulp en instrumente om die saad vir die toekoms te bewaar sodat die kerk nie ontvolk word vanweë foute van die herders en bedienaars nie. Om 'n meer verstaanbare woord te gebruik, sal ons dit die Skoolorde noem.

44. Die dosering van die Teologie is dié dienswerk wat die naaste is aan die amp van dienaar (van die Woord) en ten nouste verbonde is aan die regering van die kerk. Dit sal goed wees as voorlesings oor die Ou en Nuwe Testament gehou sal word.

45. Maar aangesien uit sulke voorlesings alleen voordeel behaal kan word indien 'n mens vantevore in tale en die geesteswetenskappe onderrig is, en omdat dit nodig is om op hierdie manier te sorg vir die saad van die toekoms, moet daar, om nie 'n leë kerk aan ons kinders na te laat nie, 'n Gimnasium opgerig word waarin die skoolgangers onderrig en voorberei word vir sowel die amp van dienaar as vir die burgerlike regering.

46. Die wyse waarop te werk gegaan moet word, word in die Skoolorde gevind.

47. In die stad sal daar nie ' $n$ ander skool vir jong kinders wees nie maar die dogters sal, soos dit vantevore die geval was, 'n aparte skool hê. (Vertaling van Pont 1981:28-29)

\section{Identifisering van sake wat eie aan die Geneefse skoolorde is}

Verskeie sake kan onderskei word wat Calvyn se skoolorde van 1559 van ander bestaande skoolordes van destyds onderskei (Van't Veer 1942:94) ${ }^{16}$. Dit kan soos volg saamgevat word:

15.Coetzee (1959:46) merk op: 'Sy Kerkordonnansie van November 1541 getuig dan ook weereens van sy vurige wens na 'n goeie skool en van sy hoë agting vir die onderwyser. Hy noem die docteur in dieselfde verband as die drie kerklike ampte van predikant, ouderling en diaken'. Raynal III (1990:125) stel in hierdie verband die volgende: 'Calvin describes the doctors or teachers as 'the order of the schools' and says that the lecturers in theology, by which he means Old and New Testament, are joined with the ministers in the government of the church This polity of governance grew in part out of his own evolving role in the Genevan church. He was called as 'Reader in Holy Scripture to the Church in Geneva'. He was a professor before he was a preacher. Of course, his work included preaching and a host of administrative tasks'.

16.Van't Veer (1942:94) verwys na die skoolorde van Calvyn as: 'een nieuw begin. Het was een belangrijk feit, dat behalve in het Latijn, ook onderricht werd gegeven in het Grieksch en in het Hebreeuwsch, terwijl ook de Fransche taal (wellicht voor het het Grieksch en in het Hebreeuwsch, terwijl ook de Fransche taal (wellicht voor het
eerst) een aparte plaats op het rooster kreeg. Het meest kwam het eigen karakter uit bij het onderricht in de leer der Heilige Schrift'. 
- Almal wat aan die onderwys deel het, leermeesters sowel as leerlinge, moet Godvresend in hulle doen en late wees (Van Veen 2006:70).

- Onderrig op die skool en onderrig in die kerk sluit direk by mekaar aan.

- Skole behoort deur die inisiatief van die ouers gestig te word. $^{17}$

- Die plig om die ouers tot die stigting en onderhouding van gereformeerde skole aan te spoor, rus op die kerke (Bouwman 1970:521).

- Die kerke hou toesig oor die skole, maar nie oor die onderwys (leerplanne en skoolbestuur) as sodanig nie. Hulle toesig gaan wel oor die Christelike karakter en oor die nakom van die doopbelofte. ${ }^{18}$ Sodoende staan almal wat by die skool betrokke is, onder die opsig en tug van die plaaslike kerk.

- Die leermeesters asook die studente aan die Akademie verbind hulle openlik aan die geloofsbelydenis deur dit met hulle handtekening te onderskryf. ${ }^{19}$

- Ter wille van die goeie orde in die skool is daar leermeesters wat die lesse aanbied, 'n hoof wat toesig oor die leermeesters hou en 'n rektor wat die algehele toesig oor die skool het.

- In die aanbieding van die lesse word besondere aandag aan die onderrig in die Skrifte en die aanleer van Psalms en die geloofsbelydenis gegee. ${ }^{20}$ Onderrig word deur gebed gedra.

- Leerlinge word van jongs af met verskeie tale wat hulle met die oog op verdere studie moet bemeester, vertroud gemaak. Klem word op onderrig in die moedertaal geplaas. ${ }^{21}$

- Leerlinge word in redenaars- en spraakkuns opgevoed sodat hulle te alle tye die waarheid kan verdedig en dwalings kan bestry.

- Leerlinge word toegerus om in die kerk sowel as in die burgerlike lewe hulle roeping te kan uitleef. ${ }^{22}$

- Leerlinge word nie net intellektueel gevorm nie, maar opvoeding moet op die kind se vorming vir die hele lewe in al sy fasette gerig wees (Van't Veer 1942:114).

- Ferm, dog sinvolle dissipline word toegepas. Skooltyd word optimaal benut en geen versuim van klasse word geduld nie.

\section{Boublokke vir'n gereformeerde skoolorde}

Dit is onmoontlik om alles wat Calvyn in sy skoolorde neergelê het net so op die lewe van die een-en-twintigste

17.Bouwman (1970:521) beroep hom hiervoor op die Skrif, naamlik Deuteronomium 4:9, 10; 6:7, 20; Efesiërs 6:4; Kolossense 3:20, 21.

18.Die wyse waarop die toesig uitgeoefen word, word onderling gereël (Bouwman 1970:521).

19.Die onderskrywing van die belydenis vind neerslag in die leer en die lewe van die personeel en die studente. Die ganse onderrig het ' $n$ religieuse karakter wat vanuit die skrifgebaseerde belydenis gerig word (Van't Veer 1942:112).

20.In sy boekie, De school van Calvijn: De betekenis van de belijdenis voor onderwijs, toon Antoon Breen (2009) aan hoe konkreet die Drie Formuliere van Enigheid in ' $n$ klassituasie verkondig kan en behoort te word.

21.Sien ook Meijer (1994:37): 'Die Christelike Skool behoort die onderrig in die moedertaal aan te bied'.

22.'Alle onderricht moet er toe brengen om God beter te leren kennen en naar Zijn Woord het leven al meer te richten' (Van't Veer 1942:113). eeu toe te pas, asof 'n duplikaat van daardie orde vandag tot heil van die skoolgemeenskap sou strek. Die lewe in die middel van die sestiende eeu en vandag is totaal verskillend (Raynal III [1990:131]). In Calvyn se skoolorde is daar heelwat praktiese reëls vervat wat logieserwys in ' $n$ stel skoolreëls verwerk kan word. Buitendien moet die norm vir 'n skoolorde nie in die geskiedenis en in die werk van mense gesoek word nie, maar in die Woord van God. Dit neem egter nie die feit weg dat daar heelwat in die skoolorde van Genève vervat is wat vir die een-en-twintigste-eeuse gereformeerde onderwys van groot waarde sal wees nie.

Enkele lyne word vervolgens getrek wat as boublokke vir 'n gereformeerde skoolorde kan dien.

\section{Vertrekpunt: Christusregering}

Die regering van Christus oor alles in die lewe, ook oor die onderwys, is die bane waarbinne die onderwys prakties gestalte moet kry. ${ }^{23}$ Die skool moet gevolglik belydenisgefundeerd wees. ${ }^{24}$ Die Drie Formuliere van Enigheid, waarin Christus as die Hoogste Profeet en Leraar, die enigste Hoëpriester en die ewige Koning bely word, is onmisbaar in die skoolorde van 'n gereformeerde skool.

\section{Leerkragte}

Leerkragte by die skool moet aan hulle Godsvrees, ${ }^{25}$ toewyding, stiptelikheid (Arso 2002:17), kundigheid en voortgesette selfstudie geken word. ${ }^{26}$ In hulle leer en lewenswandel moet hulle 'n voorbeeld vir die skoliere wees. Omdat hulle in hulle onderrigwerk aan die regering van Christus onderworpe is, moet van leerkragte verwag word om die Drie Formuliere van Enigheid te onderskryf en te onderteken.

\section{Ouers}

Van ouers word verwag om ten nouste by die skool betrokke te wees. Die belofte by die doopvont om die kind in die vrees van God te onderrig, kan nooit aan iemand anders oorgedra word nie, ook nie wanneer daar belowe word om die kind te 'laat onderrig' nie. Vir die 'laat onderrig' bly die ouers primêr verantwoordelik (Arso 2002:16). Ouers moet dus intens by die skool betrokke wees, sowel by dit wat die

23.Calvyn beklemtoon dat 'de wetenschappen haar grenzen houden, als dienares en niet als meesteres zich gedragen. Dit gebeurt, wanneer zij aan Gods Woord en Geest volstrekt onderworpen zijn. De vroomheid, het geloof, moet als haar fondament worden erkent' (Nauta 1959:19).

24. Raynal III (1990:132) merk tereg op: 'The loss of an explicit confessional base in many church colleges undermines their ability to gather students and faculty for worship, to develop consensus in personal and social values on and off campus, to employ Christian faculty, to shape a sense of commitment to the ministry and lay ministry of the church, and to foster a vocation as God's call to service in daily life. If church colleges are completely secularized, using as their primary organizational standards only from education in general, the church will have to re-establish new means of affirming Christian commitment in higher education'.

25.Sien Meijer (1994:44): 'Die bestuur van die Christelike skool moet toesien dat die onderwysers hulle in hulle gedrag en arbeid in die skool aan die Heilige Skrif en die belydenis van die kerk onderwerp'.

26.'n Goeie leraar bly lewenslank 'n student. Programme vir voortgesette opleiding van leerkragte is gebiedend noodsaaklik, veral wat gereformeerde onderwys in Suid-Afrika betref aangesien dit nog in ' $n$ beginstadium is. Meijer (1994:46) skryf in hierdie verband: 'Die bestuur van die Christelike skool behoort die onderwysers in hierdie verband: 'Die bestuur van die Christelike skool behoort die onderwysers
die geleentheid te bied om hulle steeds beter vir die opvoeding van en die onderrig aan die kinders van God toe te rus'. 
kind leer, as die manier waarop die onderrig plaasvind. Van ouers word verwag om die Drie Formuliere van Enigheid te onderteken en hulle daardeur openlik aan die regering van Christus te onderwerp.

\section{Leerlinge}

Gelowige ouers se kinders is kinders van God (Arso 2002:19-22). Daardie kinders, wat leerlinge aan die skool is, moet begelei word om in ywer, leergierigheid, gehoorsaamheid en stiptheid te groei. Van die leerlinge word verwag om dit wat hulle leer in hulle lewe te vergestalt.

\section{Leerplan}

Die leerplan van die skool moet in sy verskeidenheid van fasette (Aros 2013:44-50) op die jeug se toerusting vir koninkryksdiens ${ }^{27}$ gerig wees. Onderrig in die Skrif en die belydenis, vakkeuses en die gerigtheid van vakke ${ }^{28}$ asook buitemuurse aktiwiteite moet een doel voor oë hê, naamlik dat die kind die Here bo alles sal liefhê en sy naaste soos homself. 'Die Woord van God behoort die vakonderrig in die Christelike skool te deurdring' (Meijer 1994:41).

\section{Akademiese gerigtheid}

Jongmense word geleer om respekvol met ander vakdissiplines om te gaan, om met hulle vermoëns in die gemeenskap diensbaar te wees, om histories bewus te wees en toekomsgerig te leef en om filosofies en moreel hoogstaande te dink (Raynal III [1990:132]).

\section{Dissipline}

Kinders moet op skool met duidelike grense opgroei. ${ }^{29}$ Met die oog daarop moet gepaste tugmaatreëls neergelê word indien die grense oorskry sou word. Dissipline moet egter met liefde gehandhaaf word (Aros 2013:56-65). 'Die Christelike skool behoort tot handhawing van Christelike orde Skrifgefundeerde reëls vas te stel en elkeen daaraan te bind' (Meijer 1994:52).

\section{Organisasie, bestuur en administrasie van die skool}

Die eiestandigheid van die skool (ook tersiêre onderwys ${ }^{30}$ ) is van wesenlike belang. Ouers aanvaar verantwoordelikheid

27.Meijer (1994:25) merk in hierdie verband op: 'Die Christelike skool se doel met die opvoeding moet wees om - in aansluiting by die opvoeding in die Christelike gesin en in die Christelike kerk - die kinders van God tydens die bybring van die nodige kennis, insig en vaardighede in die lewe in die verbond met God te begelei'.

28.Van't Veer (1942:117) poneer: 'Alles was er op gericht om menschen te vormen, die hun God zouden kennen en belijden; die door den wil des Heeren zich in hun gansche leven zouden laten regeeren en dezen wil betrachten. De school wilde instrument zijn voor de uitbreiding van het koninkrijk Gods en de kerk des Heeren'.

29.Vergelyk Efesiërs 6:1-4 en Kolossense 3:20-22.

30.Vergelyk J.Chr. Coetzee (1959:49), destydse Rektor van die PU vir CHO, se opmerking in Koers: 'Die geheim van die welslae van Calvinistiese onderwys lê in die gedissiplineerdheid, die gewetensgetrouheid, die geloofsoortuiging, die selfopoffering, onder die seënende hand van die Here, tot Wie se eer alleen al hierdie dinge deur sondige mense gedoen word. Soli Deo Gloria! ... En wat is die toekoms van ons Universiteit? Dit sal sy Christelik-historiese karakter handhaaf toekoms van ons Universiteit? Dit sal sy Christelik-historiese karakter handhaa alleen solank sy oorspronklike oprigters, sy trustees, sy ondersteuners, sy dosente en studente en sy oud-studente dit help om die karakter te behou. Sonder die Geformeerde Kerk en die gereformeerde gemeenskap sal dit dieselfde we opgaan as die Geneefse Akademie van Calvyn. [Laasgenoemde het] mettertyd die ondersteuning van die Gereformeerde Kerk en gemeenskap verloor. En vandag bestaan dit nog as die Université de Genève.' vir die daarstel en instandhouding van die skool. Kerkrade sien toe dat die onderrig in die vrees van die Here geskied. ${ }^{31}$ Die onderskeie take van die hoof, die onderwysers en die administrateur(s) word deeglik omskryf sodat elkeen sy roeping in verantwoordelikheid voor Christus kan uitleef (vgl. Meijer 1994:55-62).

\section{Gemeenskap van skole en onderwysinstellings}

Daar is kragtens die gemeenskap van heiliges 'n plig om mekaar by te staan in die beskikbaarstelling van mannekrag, kurrikulumontwikkeling en onderwysvisitasie tussen die verskillende gereformeerde skole (Buys 2010:24-25).

\section{Vergaderings en samekomste}

'n Skoolorde moet die gesag vir die volgende samekomste of vergaderings reël:

- Tussen kind en onderwyser (byvoorbeeld in die klaskamer).

- Tussen kinders en onderwysers (waar die skool as 'n geheel bymekaarkom).

- Tussen ouers.

- Tussen ouers en onderwysers.

- Tussen bestuurslede onderling en die bestuur met die onderwysers.

- Tussen skole met dieselfde belydenis.

- Tussen kinders onderling in 'n leersamekoms (Buys 2010:24).

\section{Slotgedagte}

Boublokke vorm nog geen geheel nie. Dit vorm slegs dele van die geheel. Met hierdie blokke kan onderwyskundiges en ander belanghebbendes egter aan die daarstel van ' $n$ skoolorde werk waaraan skole 'n dringende behoefte het. Skole op gereformeerde grondslag wêreldwyd behoort 'n eenderse, vaste basis te hê waarop hulle met mekaar in verband staan. Hierdie vaste basis vind sy neerslag in 'n skoolorde waarin Christus as die hoogste leermeester erken en gerespekteer word. Plaaslike omstandighede wat in elke skool se konstitusie en skoolrëels verdiskonteer word, word deur die orde wat die gees van die Skrif adem, gerig en bepaal.

\section{Erkenning Mededingende belange}

Die outeur verklaar dat hy geen finansiële of persoonlike verbintenis het met enige party wat hom nadelig kon beïnvloed het in die skryf van hierdie artikel nie.

\section{Literatuurverwysings}

Akademie Reformatoriese Opleiding en Studie (Aros), 2013, Boustene vir Christelike normatiewe onderwys, Aros Uitgewery, Pretoria.

Aksie Reformatoriese Skoolonderwys (Arso), 2002, Dit is Gereformeerde onderwys: Gereformeerde vakbenaderings, Arso, Pretoria.

Bakhuizen van den Brink, J.N. \& Dankbaar, W.F., 1980, Handboek der kerkgeschiedenis, deel 3, De Tille, Leeuwarden.

31.Kerkordelik is dit in die Gereformeerde Kerke in Suid-Afrika soos volg gereël: 'Die kerkrade moet toesien dat die ouers die skoolonderrig aan hulle kinders in die vrees van die Here laat geskied' (GKSA [1998] Kerkorde, Artikel 21). 
Bouwman, H., 1970, Gereformeerd kerkrecht, Eerste deel, Kok, Kampen.

Breen, A., 2009, De school van Calvijn: De betekenis van de belijdenis voor onderwijs, Uitgeverij Woord \& Wereld, Bedum. (Woord \& Wêreld 82)

Buys, A.L.A., 2010, Eerstelinge van God: Onderwys vanuit die Verbond, Aros Uitgewery, Pretoria.

Calvyn, J., 1981, Kategismus, vert. H.W. Simpson, Potchefstroomse Teologiese Publikasies, Potchefstroom

Calvin, J., n.d., Calvini Opera Database 1.0, edited by Instituut voor Reformatieonderzoek, Instituut voor Reformatieonderzoek, Apeldoorn.

\section{CO, kyk Calvin}

Coetzee, J.Chr., 1959, 'Die Geneefse Akademie van Calvyn', Koers 37(3), 3.

Doumergue, E., 1907, Calvijn en Genève, vertaald door W.F.A. Winckel, Kirchener, Amsterdam.

Gereformeerde Kerke in Suid-Afrika (GKSA), 1998, Kerkordeboekie van die Gereformeerde Kerke in Suid-Afrika soos gewysig deur verskillende sinodes, V \& R Gereformeerde Kerke
Drukkers, Pretoria.

Gereformeerde Kerke in Suid-Afrika (GKSA), 2009, Die Psalmboek, Lux Verbi.BM, Paarl.
Maag, K., 2000, 'Calvin's academic and educational legacy', in The legacy of John Calvin, Papers presented at the 12th Colloquium of the Calvin Studies Society April 22-24, 1999, CRC Product Services, Michigan.

Meijer, J.G., 1994, Watter skool?, Printburo, Pretoria.

Nauta, D., 1959, 'Calvijn en zijn Academie te Genève', in Redevoeringen in een publieke zitting van den senaat der Vrije Universiteit gehouden op 22 Mei 1959, Kok, Kampen.

Pont, A.D., 1981, Die historiese agtergronde van ons kerklike reg, deel 1, Kital, Pretoria.

Raynal, C.E. III, 1990, The place of the Academy in Calvin's polity, Westminster John Knox Press, Louisville. (John Calvin and the Church - a prism of Reform.)

Strohm, C., 2009, Johannes Calvin: Leben und Werk des Reformators, Verlag Beck, München.

Suid-Afrika, 2014, Curriculum and assessment policy statements (CAPS), besigtig 03 September 2014, by http://www.education.gov.za/Curriculum

Van Veen, M., 2006, Calvijn, Kok, Kampen.

Van't Veer, M B., 1942, Catechese en catechetische stof by Calvijn, Kok, Kampen. 